\title{
"A HISTÓRIA QUE A HISTÓRIA NÃO CONTA": HETEROTOPIAS DE UM SAMBA-ENREDO NO CURRÍCULO
}

\author{
Danilo Araujo de OLIVEIRA ${ }^{i}$ \\ Anderson FERRARI ${ }^{\mathrm{ii}}$ \\ Carla CHAR ${ }^{\text {iii }}$
}

\begin{abstract}
RESUMO
Considerando o currículo um território de multiplicidades, este artigo explora o conceito de heterotopias de Michel Foucault, acionando o samba-enredo da Mangueira de 2019. O argumento aqui desenvolvido é o de que o samba-enredo da Mangueira nos faz pensar contraespaços no currículo, necessários para a afirmação da vida e para o alargamento de possíveis nos territórios curriculares. Assim, o objetivo deste texto é discutir as possibilidades em um currículo que ultrapassem a linha do instituído, buscando, desse modo, a criação de contraespaços e alargarmento do território curricular para que nele caibam modos de vidas considerados invivíveis. Quando utilizamos o samba e o desfile para problematizar as heterotopias no currículo, vemo-nos implicados na política das subjetividades e nos outros espaços para além da Sapucaí, aqueles em que o desfile pode se desdobrar em novas construções e (des)continuidades.
\end{abstract}

PALAVRAS-CHAVE: Currículo; Heterotopias; Vidas.

\section{“THE STORY THAT HISTORY DOES NOT TELL”: HETEROTOPIES OF A SAMBA-PLOT IN THE CURRICULUM}

\begin{abstract}
Considering curriculum a territory of multiplicities, this article explores the concept of heterotopias by Michel Foucault triggering the samba-plot of Mangueira of 2019. The argument developed here is that the samba-plot of Mangueira makes us think againstspace in the curriculum, necessary for the affirmation of life and for the widening of possibilities in the curricular territories. Thus, the objective of this article is to think about possibilities in a curriculum that go beyond the line of the instituted. Thinking againstspaces, widening the curricular territory so that it fits modes of life considered to be unviable. When we use samba and the parade to think about heterotopias in the curriculum, we find ourselves involved in the politics of subjectivities and in other spaces besides Sapucaí, those in which the parade can unfold into new constructions and (de) continuities.
\end{abstract}

KEYWORDS: Curriculum; Heterotopias; Lives.

\footnotetext{
${ }^{\text {i }}$ Doutorando da Linha de Currículos, Culturas e Diferença do Programa de Pós-graduação da FaE/UFMG e membro pesquisador do Grupo de Estudos e Pesquisas sobre Currículos e Culturas (GECC) e do Observatório da Juventude. Bolsista da Capes. E-mail: danilodinamarques@ hotmail.com - ORCID iD: http://orcid.org/00000003-3222-3172.

ii Doutorado em Educação pela Unicamp. Pós-doutorado em Educação e cultura visual pela Universidade de Barcelona/Espanha. Professor na Faculdade de Educação da Universidade Federal de Juiz de Fora (UFJF). Email: aferrari13@globo.com - ORCID iD: http://orcid.org/0000-0002-5681-0753.

iii Mestranda Acadêmica em Educação (Programa de Pós-graduação em Educação: Conhecimento e Inclusão Social - PPGE/FaE/UFMG), com bolsa Capes. Membro pesquisadora do Grupo de Estudos e Pesquisas sobre Currículos e Culturas (GECC). E-mail: carlacharmes@gmail.com - ORCID iD: http://orcid.org/0000-00016042-0726.
} 


\title{
“LA HISTORIA QUE LA HISTORIA NO CUENTA”: HETEROTOPÍAS DE UN SAMBA- ENREDO EN EL CURRÍCULUM
}

\begin{abstract}
RESUMEN
Considerando el currículum un territorio de multiplicidades, este artículo explora el concepto de heterotopías de Michel Foucault, desencadenando el samba-enredo de Mangueira 2019. El argumento desarrollado aquí es que el samba-enredo de Mangueira nos hace pensar contraespacios en el currículum, necesarios para la afirmación de la vida y para la ampliación de posibles en los territorios curriculares. Así, el objetivo de este texto es discutir las posibilidades en un currículum que van más allá de la línea de lo instituido, buscando, de esta manera, la creación de contraespacios y la ampliación del territorio curricular para que en el encaje estilos de vida considerados inviables. Cuando utilizamos el samba y el desfile para problematizar las heterotopías en el currículum, nos encontramos envueltos en la política de las subjetividades y en otros espacios además de Sapucaí, aquellos en que el desfile puede desdoblarse en nuevas construcciones y (des) continuidades.
\end{abstract}

PALABRAS CLAVE: Currículum; Heterotopías; Vidas.

\section{INTRODUÇÃO}

Vivemos em uma época de intensas ameaças nos territórios curriculares. Os grupos conservadores, utilizando-se de discursos de matriz religiosa, têm produzido espaços tristes no currículo com a retirada de temas como gênero e sexualidades. Pode-se dizer que o propósito desse investimento é governar os corpos e as sexualidades de maneira específica, como aquela que reforça a heteronormatividade como única possibilidade de existência. Desse modo, os sujeitos devem corresponder aos pressupostos generificados e binários, culturalmente construídos do que é ser homem ou mulher e, ainda, dobrar sobre si a verdade da heterossexualidade como norma para viver a sexualidade. Contudo, essa época de ameaças e medos nos convoca a não somente dizer "não" a esses ataques, mas também a resistir, de forma criativa, para que possamos ir além do "não" e focar no que podemos criar nesses momentos de enfrentamentos.

Todavia, destacamos que a temática das relações de gênero e sexualidade no currículo não é a questão central deste artigo. Estamos utilizando essa temática por sua atualidade e porque o currículo, sendo um campo de disputas e tensões, pode nos ajudar a pensar a invenção de espaços de resistência. Assim, o objetivo deste texto é discutir as possibilidades em um currículo que ultrapassem a linha do instituído. Pensar contraespaços, alargar o território curricular para que nele caibam modos de vidas considerados invivíveis. Para tanto, acionamos o samba-enredo da Mangueira do ano de 2019, a fim de reiterarmos que, como lugar de luta 
permanente por regulação, ordenamento, normalização e adequação das condutas, o currículo é um espaço em que as relações de poder estão em disputa pela construção de verdades, para produzir sujeitos de determinado tipo. Marcados/as pela fabricação de espaços tristes no currículo, no ano de 2019, deparamo-nos, no carnaval, com a criação de espaços alegres, com viabilidades de inventarmos heterotopias no currículo, considerando a heterotopia de um samba-enredo e tomando como princípio de que toda sociedade constitui suas heterotopias.

Se podemos afirmar que estes são tempos difíceis, esta também é uma época de contraespaços curriculares. Contraespaço é um conceito do arcabouço foucaultiano para pensar as heterotopias. Segundo o autor, nossa sociedade foi capaz de organizar seus próprios contraespaços, suas "utopias situadas", como denomina Foucault (2009). Esses seriam os lugares reais, fora de todos os lugares, por exemplo, os parques e jardins nos centros urbanos, os cemitérios, as prisões, os cabarés, entre outros. Queremos imaginar que, nos currículos, também se organizam esses contraespaços. Currículo está sendo entendido, neste artigo, como "um território de multiplicidades de todos os tipos, de disseminação de saberes diversos" (PARAÍSO, 2010, p. 588) e, portanto, um "lugar que pode funcionar 'como uma espécie de contestação' do 'espaço em que vivemos' e do próprio currículo já instituído" (PARAÍSO, 2018, p. 214). É essa potencialidade do currículo como espaço de reflexão, de ação e de resistência criativa que estamos chamando de contraespaços curriculares.

Queremos sonhar o sonho de Foucault ao trazer, para este artigo, o conceito de heterotopia. O sonho do autor se refere a uma ciência "que teria por objeto esses espaços diferentes, esses outros lugares, essas contestações míticas e reais do espaço em que vivemos" (FOUCAULT, 2013, p. 20-21). Em seu sonho e proposta de construir uma ciência que estude os espaços absolutamente diferentes, Foucault (2009) nos instiga a pensar sobre as heterotopias. A heterotopia sempre adota formas variadas, de maneira que não há, no mundo, uma só heterotopia constante. Com a proposta de contar, na Sapucaí, "a história que a História não conta", a escola de samba Estação Primeira de Mangueira se propôs e nos convidou a olhar para a História, para o que constitui o currículo e a disciplina História ${ }^{1}$, a partir da invenção de outros espaços.

Não é de hoje que as escolas de samba do Rio de Janeiro, o carnaval mais famoso do Brasil, se aproximam de temas e personagens da História. Durante o Estado Novo de Getúlio Vargas (1937-1945), as escolas eram obrigadas a tratar de assuntos da história nacional oficial, 
aquela que estava presente nas escolas e que reforçava determinado pertencimento nacional. Em 2000, ano em que se comemoraram os 500 anos do "descobrimento" do Brasil, as escolas de samba do Rio acordaram de homenagear esse fato histórico num ufanismo que marcou todos os sambas, abrindo mão de uma crítica dessa visão eurocêntrica de descobrimento. Assim, já passaram pela avenida temas e personagens da história oficial, como Santos Dumont, homenageado pelo Salgueiro em 2002; a Semana de Arte Moderna, contada pela Estácio de Sá em 1992; Roma e Egito antigos, no samba da Beija Flor de 1977, entre outros, que demonstram que há um currículo que é colocado em vigor nos sambas-enredos.

Entretanto, a ideia da Mangueira, para o carnaval de 2019, era homenagear os heróis e heroínas que não aparecem na história oficial. Entre estes/as, a vereadora carioca Marielle Franco, conhecida por sua militância a favor das causas sociais marginalizadas e que foi violentamente assassinada em 2018. Marielle e tantas outras pessoas "de luta", comumente, estão fora da História ensinada e tomada como verdade em muitos currículos.

Se, desde muito tempo, os sambas-enredos se aproximaram da História oficial, hoje vivemos um momento marcado por outra postura que nos convoca a pensar as condições de emergência de sambas-enredos críticos e que refletem tanto a atualidade como as histórias esquecidas, por não serem contadas. Um exemplo dessa mudança de atitude se vê nos sambas da Mangueira e da Portela para o carnaval de 2020, que trazem críticas contundentes aos lugares que pobres e índios ocupam em nossa sociedade ${ }^{2}$. Podemos dizer que as novas forças dos movimentos sociais, étnicos, de gênero e de diversidade sexual conquistaram lugar reivindicando outras formas de conhecer, ser e estar no mundo, levando as discussões dessas temáticas para além das fronteiras de seus grupos de pertencimento, alcançando os espaços públicos. Trata-se de outro conhecimento que passa pela crítica ao currículo da História, entendendo esse currículo não mais como registro fiel dos acontecimentos do passado, de uma crítica ao modo como a história foi construída e disseminada, operando com a ideia de seleção que compõe o currículo da História.

Isso significa que, se vários acontecimentos e personagens foram lembrados e entraram para o currículo da História, outros tantos ficaram silenciados, esquecidos e seus nomes foram, propositadamente, apagados. Hoje, o discurso do homem branco vencedor, católico e heterossexual tem sido problematizado nos campos da História e do Ensino de História, chegando também às quadras das escolas e às avenidas por meio dos grandes desfiles. Esse 
movimento de trazer causas sociais e novas propostas de pensar a sociedade e os espaços do conhecimento para a avenida se mantém presente para o desfile da Mangueira do ano de 2020, reforçando, para nós, a ideia de que o samba-enredo e as escolas de samba podem nos inspirar a refletir acerca de contraespaços curriculares.

Um trecho do samba da Mangueira de 2019 que nos convida a ampliar nossos conhecimentos a respeito dos heróis e heroínas nacionais e do currículo que aprendemos na escola diz o seguinte: "Brasil, chegou a vez/ De ouvir as Marias, Mahins, Marielles, malês". O trecho nos traz uma questão: “quem são as Marias, Mahins, Marielles e malês?”, provocandonos a pensar por que muitas mulheres e alguns grupos étnicos e sociais não fazem parte do currículo de História. O samba-enredo investe nesse desconhecimento e nos provoca a conhecer "o avesso de um mesmo lugar", em outras palavras, o avesso de uma mesma História, o avesso de um currículo.

Luíza Mahin foi uma mulher negra escravizada e um dos mais relevantes nomes que lutou na revolta dos Malês, em 1835. Malês era como se chamavam as pessoas escravizadas vindas de regiões muçulmanas da África que geralmente sabiam ler e escrever em árabe, distinguindo-se de uma população brasileira da época que era, em sua maioria, completamente analfabeta. Maria é uma referência a outra mulher negra escravizada - Maria Felipa de Oliveira - que está fora da História oficial do Brasil, mesmo tendo sua importância reconhecida na resistência aos portugueses na Bahia numa luta que antecedeu a independência do Brasil. Luíza Mahin, Maria Felipa e Marielle Franco são mulheres que fizeram história, mas que não são consideradas no currículo da História. Mulheres que nos fazem pensar os lugares reservados às mulheres ainda hoje.

O samba-enredo da Mangueira de 2019 provoca as histórias já contadas que estão na ordem do verdadeiro em muitos currículos. Ele propõe contraespaços nesses territórios para contar outra história em resistência às histórias contadas para “ninar gente grande”. Daí o título do samba-enredo: História pra ninar gente grande. Segundo o carnavalesco da Escola de Samba, "uma história pra ninar gente grande" foi a que nos foi contada na escola e nos adormece quando adultos: "conta-se uma história na qual as páginas escolhidas o ninam na infância para que, quando gente grande, você continue em sono profundo"3.

Todos os anos, a força dos enredos das escolas de samba toma conta das comunidades para, depois, invadir os sambódromos, as telas da televisão, o ciberespaço. Em nosso 
entendimento, o samba-enredo da Mangueira, do ano de 2019, pôde invadir e servir para tensionar o currículo ao propor a invenção de espaços outros para falar das histórias escondidas de mulheres, pobres, negros e indígenas, viabilizando um alargamento do possível no currículo para afirmar vidas. Pela repercussão do desfile, podemos e ousamos pensar que essas escolhas afetaram as escolas de Educação Básica, instituições responsáveis por nos contarem a História oficial e que também constroem currículos e ensinam conhecimentos em negociação com o que acontece em outros espaços sociais. Esses espaços outros que podem ser criados no currículo evidenciam que "ao lado do poder há sempre potência. Ao lado da dominação há sempre insubordinação" (NEGRI, 2001, p. 236). Mostram, ainda, que algumas coisas nos parecem como dadas, naturalizadas e cristalizadas, mas "é preciso fazer do pensamento uma conspiração cotidiana, uma insurgência indomável”4 (PELBART, 2017). É necessário fazer pensar, questionar o que é entendido como natural, especialmente em tempos de ódio como o que vivemos. Nesse sentido, os espaços outros no currículo podem acionar uma vontade de potência, uma "vontade de mais" (NIETZSCHE, 2011, p. 104), ou, ainda, "vontade de durar, de crescer, de vencer, de estender e intensificar a vida" (PARAÍSO, 2018, p. 237).

Os contraespaços são esses espaços outros que criamos nos espaços formais e formatados para se contraporem ao instituído, numa coexistência que é, ao mesmo tempo, mítica e real. Espaços esses que podem ser criados para afirmar a vida onde ela não é passível de luto, de importância (BUTLER, 2018), a fim de dizer que ela é, sim, possível de viver, e viver de modos que não seriam autorizados. São esses contraespaços que nos interessam e, neste artigo, queremos pensar nos territórios curriculares, pois, apesar de todas as tentativas de controle, por se tratar de um território de disputas, os currículos são também espaços para invenção, para contestação do já instituído, pois “os currículos não podem escapar das criações e fissuras" (RANNIERY, 2018, p. 206). Assim, vamos explorar, a partir do samba-enredo da Mangueira do carnaval de 2019, as heterotopias no currículo, a fim de refletirmos sobre as possibilidades dos contraespaços nos territórios curriculares. O argumento aqui desenvolvido é o de que o samba-enredo da Mangueira nos faz pensar nesses contraespaços, necessários para a afirmação da vida e para o alargamento de possíveis nos territórios curriculares. Não significa considerar o samba-enredo como currículo, mas como ele - o samba-enredo - nos conduzir a tratar das possibilidades de invenção de heterotopias no currículo. Como esse samba-enredo nos faz pensar em contraespaços curriculares? 


\section{DAS HETEROTOPIAS}

O século XIX foi marcado por uma obsessão pelo tempo. Em contrapartida, parece prevalecer, na atualidade, o interesse pelo espaço. Essa é uma suposição foucaultiana para falar de um crescente entusiasmo pelo espaço nas sociedades contemporâneas, o qual é composto do simultâneo, da justaposição, do próximo e do longínquo, do lado a lado e do disperso, devendo também ser compreendido em sua relação com o tempo. Nas palavras de Foucault (2009, p. 466), um “entrecruzamento fatal”. Desse modo, o espaço tem uma história. O autor usa a Idade Média para exemplificar como o espaço era compreendido, nesse tempo, como um espaço de localização. Trata-se de um conjunto de espaços hierarquizados e divididos entre sagrados e profanos, protegidos e sem defesa, urbanos e rurais, supracelestes, celestes e terrestres. A partir do século XVII, Galileu constitui um espaço infinito e infinitamente aberto, mudando-se a forma como o espaço/lugar era visto. Dissolve-se a compreensão de "lugar" da Idade Média para passar a entendê-lo como um "ponto em seu movimento". Na atualidade, o espaço "é definido pelas relações de vizinhança entre pontos ou elementos: formalmente, podem-se descrevê-las como séries, organogramas, grades" (FOUCAULT, 2009, p. 412).

O espaço, nessa nova configuração, é, assim, objeto de investimento de técnicas e de relações de saber que permitem determiná-lo ou formalizá-lo, porém, mesmo com todo o investimento empreendido, o espaço ainda tem regiões sacralizadas. Há oposições dadas, muitas vezes intocadas que comandam nossas vidas, por exemplo, as oposições entre espaços público e privado, familiar e social, cultural e útil, de lazer e de trabalho. Foucault retoma as análises de Bachelard e as descrições de fenomenólogos para mostrar outra característica do espaço: ele é cheio de qualidades, não é um espaço homogêneo e vazio. Contudo, essas análises se restringem a "espaços de dentro", enquanto Foucault (2009) se importa mais com o "espaço de fora". Assim, no tocante aos posicionamentos disponibilizados e possíveis, o que interessa a Foucault são aqueles que têm a

[...] curiosa propriedade de estar em relação com todos os outros posicionamentos, mas de um tal modo que eles suspendem, neutralizam ou invertem o conjunto de relações que se encontram por eles designadas, refletidas ou pensadas (FOUCAULT, 2009, p. 414). 
Com relação a esses espaços, chamaram a atenção do autor dois tipos, a saber: as utopias e as heterotopias. As utopias são posicionamentos sem lugares reais ou, ainda, irreais propriamente. Por sua vez, as heterotopias são espécies de contraposicionamentos provavelmente presentes em qualquer cultura. Trata-se de utopias efetivamente realizadas, de modo que os "posicionamentos reais que se podem encontrar no interior da cultura estão ao mesmo tempo representados, contestados e invertidos" (FOUCAULT, 2009, p. 415). Esses espaços de interesse foucaultiano não são as localizações medievais, nem as extensões de Galileu, tampouco os espaços usuais do cotidiano ou mesmo espaços inventivos da ficção, são "lugares que se opõem a todos os outros, destinados, de certo modo, a apagá-los, neutralizá-los ou purificá-los. São como que contraespaços" (FOUCAULT, 2013, p. 20).

Para a análise e a descrição das heterotopias, é preciso ter em mente alguns princípios. As heterotopias estão, provavelmente, em todas as culturas, mesmo que não da mesma forma, e se dividem como heterotopias de crise e de desvio. A primeira, em extinção na contemporaneidade, refere-se àqueles lugares privilegiados, sagrados ou proibidos, designados àquelas pessoas que estão em crise com relação à sociedade. A segunda é "aquela na qual se localizam os indivíduos cujo comportamento desvia em relação à média ou à norma exigida" (FOUCAULT, 2009, p. 416). Outro princípio é o de que as heterotopias mudam de função em determinada sociedade com o decorrer do tempo. Elas também têm o poder de justaposição, com o objetivo de "justapor em um só lugar real vários espaços, vários posicionamentos que são em si próprios incompatíveis" (FOUCAULT, 2009, p. 418).

Além disso, a relação das heterotopias com o tempo é diferente, pois estão em ruptura com o tempo tradicional, o qual pode se acumular ou ser bastante fútil, passageiro e precário. As heterotopias são, ainda, compostas de um sistema de abertura e fechamento, sendo passíveis de isolamento e penetração. Enfim, o último traço das heterotopias é que elas têm uma função, que se desenvolve de maneiras extremas. Elas podem denunciar um espaço real como mais ilusório que um espaço de ilusão criado ou, pelo contrário, produzir outro espaço real, marcado pela perfeição e meticulosidade que podem evidenciar o restante dos espaços como mal organizados e desordenados.

Em síntese, podemos dizer que as heterotopias são "a contestação de todos os outros espaços" (FOUCAULT, 2013, p. 28) e, por essa razão, são contraespaços ou, segundo a etimologia da palavra, outro lugar (hetero - diferente, outro, topos - lugar). Portanto, as 
heterotopias estão, de alguma maneira, em ligação com um espaço dado, mas a relação com os outros modos de ocupação é de contradição. As heterotopias "dessecam o assunto, detêm as palavras sobre si mesmas, contestam, desde a sua raiz, toda a possibilidade de gramática; desfazem os mitos e tornam estéril o lirismo das frases" (FOUCAULT, 1999, p. XIII). Embora não seja possível estar fora das complexas redes das relações de poder, as heterotopias são espaços outros criados que evidenciam possibilidades de transformar uma situação dada.

Destarte, ao discutir sobre heterotopias, estamos considerando os espaços de "fora", que são aqueles espaços nos quais vivemos e pelos quais nós somos, de alguma maneira, "atirados para fora de nós mesmos, dentro dos quais se desenvolve a erosão de nossas vidas, de nossos tempos e de nossas histórias; são os espaços que nos correm e que nos arregaçam eles mesmos a um espaço heterogêneo" (POCAHY, 2006, p. 95). Assim, a reflexão que queremos propor aqui é como criar contraespaços no território curricular. Como instaurar possibilidades outras que afirmem a vida nos jogos de poder-saber curriculares, isto é, pensar quais deslocamentos, invenções e ocupações de outros espaços podem ser produzidos no currículo, capazes de oferecer alegria, prazer e fazer desejar.

Atentos/as à relevância dos espaços na atualidade, compreendemos que os sambasenredos podem, ao ocupar espaços, criar espaços de resistência e invenção, produzir contraespaços, inclusive no currículo de História. Isso porque partimos de uma perspectiva de História que propõe problematizar nossas questões atuais ancorados/as em uma ideia de História como construção, que passa pelas relações do saber-poder. Nesse sentido, a História pode ser entendida como produção discursiva (JENKINS, 2011), com inspiração na teoria foucaultiana de que das práticas discursivas resultam efeitos. A historiografia e o currículo de História produzem efeitos na medida em que produzem sujeitos e suas formas de conhecer a realidade. Com base nessa ideia, o discurso do homem branco, vencedor, católico e heterossexual, que dominou a história do Brasil, está sendo desmitificado, provocando historiadores e historiadoras a pensarem a História como discurso, como narrativas que constroem, reproduzem ou desconstroem determinados saberes e objetos históricos. A construção de espaços heterotópicos passa por essa problemática da história como construção que possibilita narrar e dar vida a histórias desconhecidas, a pessoas sem visibilidade histórica e, assim, investir e criar outras formas de ser e estar no mundo atual e no currículo. 
Quando os sambas-enredo propõem uma crítica social ancorada em um novo saber da História, eles estão imersos em jogos de poder e saber. Como argumenta Jenkins (2011, p. 23), "a história constitui um dentre uma série de discursos a respeito do mundo. Embora esses discursos não criem o mundo (aquela coisa física na qual aparentemente vivemos), eles se apropriam do mundo e lhe dão todos os significados que têm". Em outras palavras, o autor quer dizer que a história e o passado são coisas distintas, que não estão unidas, de maneira que não temos somente uma forma de leitura da história do passado. $\mathrm{O}$ entendimento da história como construção é fundamental para seu reconhecimento como contraespaço, como espaço de luta e de resistência, porque a maneira como pensamos e agimos diz de uma perspectiva histórica que está ancorada na história do pensamento. Como estão livres um do outro - história e passado , estão distantes entre si no tempo e no espaço, o que faz com que o mesmo objeto de investigação possa ser contado com base em diferentes práticas discursivas. Tendo o sambaenredo da Mangueira (2019) sido composto depois de muita pesquisa, com consultas a teses, dissertações e professores e professoras de História, os autores colocaram em circulação uma perspectiva de História entendendo-a como construção discursiva e como espaço de resistência, criatividade e invenção. Ao colocar a História sob suspeita, o samba toma a avenida como espaço possível para a invenção.

Aproximando o pensamento de Foucault da História e de seu uso no samba, podemos dizer que o que está em jogo é uma necessidade de repensar a historiografia tradicional e os currículos de História, que não contempla todos os indivíduos, desconstruindo a ideia "de que a história dos fortes traz consigo a história dos fracos" (FOUCAULT, 2005, p. 81). Está em jogo não somente uma nova maneira de interpretar a História, mas também de demonstrar a coexistência de uma variedade de vidas oprimidas pelo saber, pelas relações de poder presentes nos discursos históricos que dão vida a determinados sujeitos. Assim, se é possível pensar em contraespaços, também o é em contra-histórias. Em "A vida dos homens infames", Foucault vai definir a contra-história como: "o discurso daqueles que não têm a glória, ou daqueles que a perderam e se encontram agora, por uns tempos talvez, mas por muito tempo decerto, na obscuridade e no silêncio" (FOUCAULT, 2005, p. 82).

O samba da Mangueira na Sapucaí justapôs uma contra-história em meio a esse lugar real, que são os desfiles das escolas de samba no carnaval, e convocou não somente a instituição escolar a pensar seu currículo, mas também as memórias da trajetória escolar de quem 
assistiu/assiste ao desfile, de tal maneira que podemos dizer que o samba convida a escola e as aulas de História a entrarem na avenida, justapondo dois espaços improváveis: as salas de aula e as escolas de samba. Pode-se dizer que esse contraespaço do samba-enredo da Mangueira acabou por criar um tensionamento nos territórios do currículo: por que essa história que aqui contamos não está aí nesse currículo? Mesmo que não seja possível estar fora das complexas redes das relações de poder, as heterotopias são espaços reais que evidenciam possibilidades de transformar uma situação dada.

Nesse sentido, não basta trazer, por exemplo, as mulheres para o samba. Seguindo o caminho aberto pelos historiadores sociais que defendiam uma nova história vista por baixo, as feministas radicalizaram o entendimento da história como discurso e como espaço para as contra-histórias, argumentando que não é suficiente incluir as mulheres nas grandes narrativas históricas; há necessidade de histórias plurais, investigadas, contadas e construídas por mulheres. O desafio posto é a manutenção desse contraespaço e dessa contra-história para além dos três dias de carnaval, transcendendo o desfile, de maneira que o que ocorreu no samba e no desfile ainda afete outros espaços do currículo em outros espaços-tempos do saber. De acordo com Paraíso (2015, p. 50), "um currículo, apesar de ser constituído de muitas formas, pode ser feito da mesma matéria dos sonhos, dos filmes, da vida". Assim, apostamos que o currículo pode "criar aberturas e conexões imprevisíveis" (DIAS; MARQUES; AMORIM, 2012, p. 9) em conexão com as heterotopias de um samba-enredo para fazer proliferar histórias outras, tornando vivíveis as muitas vidas no currículo que ainda parecem ser invivíveis.

\section{DOS CONTRAESPAÇOS E O PROLIFERAR DE VIDAS NO CURRÍCULO}

O samba-enredo que tomamos como inspiração trata de vidas que fizeram história e reivindica o pertencimento dessas vidas à História. Nesse sentido, compreendemos que isso nos diz que essas vidas importam. Estar na História, fazer parte da História, corresponde a um investimento em sujeitos atuais, de maneira que esse discurso sobre o passado na construção de uma história vista por baixo, em que as mulheres e as minorias como pobres, negros e indígenas participam, é uma forma de ler e compreender o mundo. Em sua defesa da História como discurso, Jenkins (2011, p. 28) afasta a ideia de relativismo que tanto assusta os historiadores e historiadoras: 
Não quero dizer com isso que nós simplesmente inventamos histórias sobre o mundo ou sobre o passado (ou seja, que travamos conhecimento do mundo ou do passado e então inventamos narrativas sobre ele), mas sim que a afirmação é muito mais forte: que o mundo ou o passado sempre nos chegam como narrativas e que não podemos sair dessas narrativas para verificar se correspondem ao mundo ou ao passado reais, pois elas constituem a "realidade".

Para o autor, "a história nunca se basta; ela sempre se destina a alguém” (JENKINS, 2011, p. 40). Essa afirmação nos provoca a pensar que a história e o currículo estarão em constante construção, sendo resultado de relações de poder, das maneiras como pessoas e grupos sociais vão contar e lutar por histórias diferentes capazes de legitimar suas existências, suas condições de vida, bem como suas práticas e discursos. O samba-enredo demonstra que a história e o currículo são conhecimentos em disputa que nos mostram que, mais do que saber o que é a história, o importante é perguntarmo-nos para quem é a história. Nesse sentido, pensar o currículo por meio do samba-enredo é evidenciar que ele é um espaço-tempo de possibilidades de inclusão de vidas não vividas.

Para pensar as heterotopias em territórios curriculares, partimos do entendimento de currículo como "espaço de possibilidades e como território onde as forças podem 'deformar' as formas de um currículo, instaurando o movimento que é fundamental para o aprender" (PARAÍSO, 2015, p. 50). O espaço das formas é constituído por ordenamentos, organizações, sequenciações, estruturações, enquadramentos e divisões (PARAÍSO, 2010), controlado por poderes que demarcam o que deve ser dito, como deve ser dito, o que fazer, como fazer. Entretanto, o currículo e o carnaval também são formados pelo espaço das forças. O espaço das forças são os vazamentos, os escapes, as resistências, pois um currículo é

[...] um território de multiplicidades de todos os tipos, de disseminação de saberes diversos, de encontros "variados" de composições "caóticas", de disseminações "perigosas", de contágios "incontroláveis", de acontecimentos "insuspeitados" (PARAÍSO, 2010, p. 588).

Portanto, consideramos o desfile da Mangueira composto por formas e forças que são capazes de nos ajudar a pensar em possibilidades de invenção de heterotopias no currículo. Podem ser reputadas formas do carnaval o samba-enredo, as alegorias, a bateria, a coreografia, a comissão de frente, as alas, as passistas, os mestres-salas etc. O que entendemos por força no samba-enredo, por sua vez, são as histórias de resistências "que o livro apagou", que não nos ensinam nas escolas ou, em outras palavras, no currículo instituído. No carnaval carioca de 
2019, entre essas formas e forças, um contraespaço foi criado, instaurando um movimento do aprender que fez "sambar" os pensamentos. Entendemos que as heterotopias são contraespaços concebidos entre as formas e forças, um lugar fronteiriço, de passagem, que produz uma realidade outra, novos espaços possíveis para viver e pensar. Pode-se dizer que as "histórias que o livro não conta", histórias essas de resistência, são as forças que, no contato com as formas do carnaval, criaram um contraespaço, fizeram mover, sambar, inventando possíveis, denunciando a mesmice e desestabilizando certezas.

O que podemos aprender com essa heterotopia para pensarmos o campo curricular? Sabendo que o currículo é território de formas e forças e que "as formas de um currículo são capazes de [...] aprisionar as forças" (PARAÍSO, 2015, p. 50), entendemos que, se privilegiarmos apenas as formas, paralisaremos o movimento e, consequentemente, o aprender. Inversamente, se privilegiarmos somente as forças de um currículo, o contato com o fora, o resultado será o caos: não se cria pensamento. Também não se aprende, pois nada se ensina. Como, no currículo, há uma tendência de favorecermos as formas em detrimento das forças, compreendemos a importância de buscar "uma saída para livrar um currículo da subordinação às formas", haja vista que tal "subordinação [é] tão antiga quanto a própria existência de um currículo" (PARAÍSO, 2015, p. 50). Daí a necessidade de, em vez de subordinação, considerarmos a coexistência de formas e forças nos territórios do currículo e, entre esses espaços, inventar contraespaços, alargando o currículo e fazendo-o proliferar vida, o invivível. As heterotopias de um samba-enredo no currículo trouxeram a força de mulheres, índios, negros e pobres, que, historicamente, ficaram subordinados/as às formas dos "porões" e "barracões". Nesse contraespaço, a Mangueira rasgou o livro com "histórias para ninar gente grande" e apresentou uma história reescrita.

Que movimento fez desse samba-enredo e desfile um contraespaço? Entendemos que houve um desejo que disparou o movimento, considerado fundamental para o aprender, como mencionado. O desejo? Viver "um país que não está no retrato", contar "a história que a história não conta", cantar "versos que o livro apagou", trazer o "avesso" do Brasil à tona e denunciar "o sangue retinto pisado" que há "atrás do herói emoldurado". Esse desejo abriu um contraespaço, propiciou-nos viver a heterotopia desse país que se faz “de Lecis, Jamelões”. Vivemos essa heterotopia nos momentos dos desfiles do carnaval de 2019, um contraespaço e 
uma contra-história que se instauram cada vez que ouvimos a letra desse samba-enredo ou quando assistimos ao desfile pelo YouTube $e^{5}$.

Como a Mangueira nos fez viver tal heterotopia? Entre as belas e coloridas formas do carnaval e a força de resistência de histórias "que a história não conta", a Mangueira abriu alas e transformou a Sapucaí, naquela noite, em um contraespaço e uma contra-história: uma grande sala de aula, com um currículo outro, um currículo que não está na ordem do "verdadeiro", um currículo de mulheres, índios, pretos e pobres, dando voz a um currículo até então silenciado, um currículo ainda não contado pelo currículo oficial. Trata-se da história de heróis e heroínas de resistência, populares, não reconhecidos e reconhecidas pela narrativa tradicional (VIEIRA, 2018) e, por isso, estão fora da escola. "Índios, negros, mulatos e pobres não viraram estátua. Seus nomes não estão nas provas escolares. Não são opções para marcar 'x' nas questões de múltiplas escolhas" (VIEIRA, 2018, n.p.). Contudo, a heterotopia verde e rosa transformou os carros alegóricos em livros, as coreografias em narrativas. Foliões e foliãs tornaram-se mestres, professores e professoras, heroínas e heróis que não ouvimos nas histórias que nos contavam na infância. Esse contato com o fora possibilitou um agenciamento entre as formas do carnaval e a força das histórias não contadas. Estremeceu o chão da Sapucaí e abriu um contraespaço e contou uma contra-história. Criou um currículo outro que potencializou e denunciou crimes e barbáries. Fez sambar os corpos e pensamentos. Estimulou o pensar e provocou riso e alegria! A Mangueira converteu seu desfile em uma aula das histórias que os livros não contam e tornou real o desejo por um "país que não está no retrato".

Um dos trechos revela que, de fato, trata-se de uma heterotopia: "Brasil, meu nego, deixa eu te contar, a história que a história não conta, o avesso do mesmo lugar". "O avesso do mesmo lugar" nos remete à ideia de heterotopia. Trata-se de um lugar que está ali, mas escondido. Estar no avesso pode remeter a um lugar não revelado. Trazer o avesso para a superfície é dar a ele outro lugar, porquanto o lugar reservado ao avesso é o do escondido, o do que não se mostra. Coloca-se, então, o avesso lado a lado com o que lhe é contrário. O que se propõe aqui é justapor essa história outra, isto é, "justapor em um só lugar real vários espaços, vários posicionamentos que são em si próprios incompatíveis” (FOUCAULT, 2009, p. 418). Essa história outra "que a história não conta" é, de fato, incompatível com aquelas contadas, narradas e valorizadas em um currículo. 
O currículo que esse samba-enredo cria é um currículo do avesso, que não está perceptível, está silenciado, apagado e escondido "nos porões", debaixo da "poeira", nos "barracões". É secreto e furtivo, mas o que se quer é contar essa história, que pode ser curiosa e surpreendente, visto que ela é uma contestação de outra história narrada. Foucault (2013) argumenta que as heterotopias contestam, desde sua raiz, essa história que se conta, é uma história de contestação de toda possibilidade já contada, já sabida. Falamos agora de um currículo de negros, de índios, de pobres e de mulheres.

\section{4 "ESSES NOMES NÃO SERVIRAM PARA ELES. PARA NÓS, ELES SERVEM"6}

O título desta seção é uma fala do carnavalesco que contém uma intencionalidade, marcada por um "eles", que é o outro, o oficial, o tradicional, a história que insiste em se reafirmar. No entanto, também tem um "nós", reafirmando a questão levantada por Jenkins (2011), de que mais importante que discutir o que é a história, interessa-nos colocar sob investigação para quem é a história. Que "nós" se reconhece no que o samba propõe? Quem são os sujeitos convidados a comporem esse "nós" e a se sentirem representados no samba e na Sapucaí? Isso porque, se estamos questionando como o samba-enredo nos estimula a considerar as heterotopias no currículo, como ele nos faz pensar nos contraespaços curriculares, não podemos nos esquecer de que essa relação com a contra-história e com o currículo como contraespaço não acontece somente na letra, mas também no samba-enredo, ou seja, como a história que está na letra é contada no desfile, na organização da escola com suas alas, carros alegóricos, logo, estamos falando de um processo que acontece entre a canção, o visual e o expectador. Esse modo de contar e propor uma nova história convoca a escola e as aulas de História a irem para a Sapucaí. Assim, é possível encontrar pessoas que reconhecem determinados personagens históricos representados no desfile, da mesma maneira que não reconhecem alguns que não estão nas escolas e, portanto, não são reconhecíveis no desfile.

Mangueira contou a história de um país de quase doze mil anos, que foi invadido, cujo povo foi saqueado e assassinado, que teve heróis e heroínas que, embora tenham perdido batalhas, não se renderam pacificamente. Antes, tornaram-se símbolo de luta e resistência, fazendo, do que poderia ser apenas mais um desfile, a heterotopia de um país. Voltamos, assim, ao terceiro princípio da heterotopia apontado por Foucault (2013), quando ressalta que ela tem 
o poder de justapor em um só lugar real vários espaços que são, a princípio, incompatíveis. O teatro e o cinema são dois exemplos desse princípio, em que são projetados outros espaços e tempos que convocam os expectadores a viverem essas dimensões. $\mathrm{O}$ espaço da Avenida Sapucaí, local em que desfilam as escolas, também pode admitir esse princípio, de maneira que é muito comum observar expectadores que, das cadeiras, arquibancadas ou camarotes, buscam identificar no desfile personagens da história do Brasil, fazendo com que as aulas de História estejam presentes. No entanto, que aulas de História são convocadas no desfile da Mangueira? Se a escola, as aulas de História e o currículo são convidados a estarem na avenida, o desfile também pode ser levado para a escola, deslocando-se desse lugar do carnaval para a problematização do currículo na escola.

Na comissão de frente, por exemplo, foram apresentados índios e negros que estão fora dos retratos dos museus. Nesse contraespaço, os "invasores" foram "minimizados", retirados desses retratos e transformados em personagens de pequena importância. Houve uma inversão, um aspecto comum ao carnaval. Nessa inversão, os heróis e heroínas nacionais dos livros didáticos de História foram demonstrados como pequenos, de pouca importância, enquanto índios e negros assumiam os lugares de maior destaque. O que representa estar ou não nos retratos e quadros dos museus? Ao discutir as vidas precárias, Butler (2018) vai afirmar que todas as vidas são precárias, na medida em que, para ser vida, há sempre a possibilidade da morte e a dependência de um/uma outro/a para que possamos sobreviver. No entanto, se todas as vidas são precárias, a questão é que algumas vidas são mais precárias que outras. Dedicandose a pensar essa desigualdade na precariedade, o que faz algumas vidas serem passíveis de luto e outras não, Butler (2018, p. 14) vai trabalhar com a ideia do enquadramento: "as molduras pelas quais apreendemos ou, na verdade, não conseguimos apreender a vida dos outros como perdida ou lesada (suscetível de ser perdida ou lesada) estão politicamente saturadas". Que vidas estão enquadradas nos museus e que fazem parte da história? Que história essas vidas contam? Que vidas estão fora dos museus e não são consideradas vidas possíveis de ser vividas? O samba e o desfile da Mangueira também são formas de enquadramentos, eles operam igualmente com as relações de poder quando decidem contar algumas histórias, de alguns/mas personagens, dando-lhes a condição de aparição.

Assumiram esses lugares os índios e negros que, simbólica e literalmente, rasgaram o livro que "apagou versos" de histórias de resistências. A menina Cacá Nascimento entrou em 
cena e, representando Marielle Franco, abriu um novo livro com a história reescrita e nele estava a inscrição "presente". Nesse contraespaço e nessa contra-história, Marielle se fez presente e foi carregada nos ombros de um índio e de um negro. Esses contraespaços e essas contrahistórias trazem à cena vidas que não apreendemos, que não nos foram ensinadas como passíveis de ser apreendidas e, ao fazerem isso, organizam novas experiências com o saber e com o visual, investindo em novas possibilidades de sujeitos.

Um quarto princípio da heterotopia é aquele classificado como heterocronias (FOUCAULT, 2013). Por esse princípio, o autor defende que a heterotopia funciona quando os sujeitos se encontram com a ruptura absoluta com seu tempo tradicional, estando a heterotopia ligada a recortes de tempo. Olhar para o desfile da Mangueira é se voltar para o passado e perceber como este se faz presente em nossa constituição e posição de sujeito nas relações com o currículo. Esse passado-presente organiza o desfile e as intencionalidades, de maneira que o primeiro casal de mestre-sala e porta-bandeira representava um exuberante casal de índios, na tentativa de nos informar que são esses os heróis deste Brasil heterotópico. O enredo começa contando a história de índios que habitam (que habitavam e continuam ameaçados) essa terra há cerca de doze mil anos, com a produção de cerâmica considerada a mais antiga do continente americano (cerca de oito mil anos) (VIEIRA, 2018). Essa contra-história deflagra o que seriam "as mentiras" das histórias que nos ninaram na infância e nos fizeram dormir sem saber da riqueza e beleza de nossa história. No entanto, há uma armadilha que pode conduzir à ideia de uma história verdadeira e única, como se a história fosse feita de verdades absolutas. Negar uma e valorizar outra não pode representar o fim da ideia de construção como marca dessa área de conhecimento e do currículo. O samba-enredo nos faz pensar as heterotopias no currículo, de maneira que, ao defender que "não fomos descobertos há 500 anos, mas fomos invadidos há 500 anos", impõe-se um posicionamento por uma perspectiva que abandone o eurocentrismo que marcou o ensino de História e ainda está presente na Base Nacional Comum Curricular (BNCC). Destaca-se que os currículos são campos de saberes

[...] disputados, submetidos a conflitos, a uma inserção contextual capaz de produzir diferenças nas abordagens, linguagens, modos de ser e compreender o mundo. Em outros termos, são sempre particulares que em dadas relações de poder assumem o registro do universal (LOPES, 2018, p. 25). 
Uma abordagem diferente da História tradicional também está presente no segundo carro alegórico: "o sangue retinto por trás do herói emoldurado". Esse carro mostra o sangue das etnias mortas e "conquistadas". O Monumento às Bandeiras, dedicado aos Bandeirantes, localizado no parque Ibirapuera da capital paulista, aparece banhado em sangue, com palavras como "assassinos" e "ladrões" pichadas em seu entorno. A cena é forte e apresenta uma história sangrenta que causa indignação e propõe outro currículo. Mulheres empurram esse carro. Outro símbolo de luta e resistência. Após esse carro, fazendo alusão ao verso "não veio nem do céu nem das mãos de Isabel”, um carro exuberante enaltece Zumbi e Dandara, bem como a avó de Zumbi, que era princesa em seu país de origem, mas, tendo seu povo perdido uma batalha em Portugal, foi vendida como escrava. Contudo, em terras brasileiras, lutou bravamente contra a escravidão. Outro carro, correspondendo ao verso "a liberdade, é um dragão no mar de Aracati”, representa um navio negreiro que, mais do que escravos, carregava um povo com riqueza cultural e histórica. Aracati foi considerado um "dragão do mar" ao se recusar a realizar o tráfico de escravos.

Aprendemos, com a bateria "sapiência negra: negro pensante", que tivemos intelectuais negros, como o abolicionista Luís Gama, filho de Luiza Mahin, mulher que organizou o levante Malê, e que, se tivessem ganhado, teria sido rainha da Bahia. Seu nome é cantado reiteradas vezes na letra do samba. Aprendemos a história de Esperança Garcia, autora de uma carta que escreveu ao governador do Piauí, denunciando as violências que sofria em uma fazenda. Esperança Garcia foi reconhecida como a primeira mulher advogada do Brasil. "Aprendemos" foi usado propositalmente para admitir que esse espaço de diversão também ensina e que aprendemos com todos os sentidos, com o que vemos, ouvimos, sentimos, sambamos, participamos. Contudo, aprendemos desaprendendo ou nos deseducando para educar de outra forma, visto que é necessário deseducar o olhar para poder ver de outra maneira. Se não deseducamos o olhar, corremos o risco de achar o desfile e o que nos apresenta como inadequados, como não sendo a "verdadeira" história, permanecendo somente no campo da diversão e da inversão permitida para esses dias de reinado do Momo. É possível que saiamos do desfile reforçando o lugar de construção da História somente nas universidades e escolas, não nos dando a oportunidade de nos afetar com esse contraespaço e contra-história do samba na constituição do currículo. 
O carro alegórico "ditadura assassina" mostra a história reescrita. Livros compõem esse carro. Neles, figuras como "Marechal Deodoro da Fonseca", "Floriano Peixoto" e "Padre Anchieta”, com máscaras caricatas, sambam em cima de corpos ensanguentados. Trata-se do "sangue retinto pisado". Pedro Álvares Cabral aparece em uma jaula como "171", vestido de um traje típico de prisioneiro. Nessa heterotopia, Cabral é criminoso, e não herói. Ladrão, e não descobridor. Dom Pedro I aparece montado em uma mula, e não no glorioso cavalo retratado no famoso quadro "Independência ou Morte" do pintor Pedro Américo 7 .

Encerrando o cortejo, heróis populares são exaltados por suas histórias de força, de luta, de resistência. Histórias que aprendemos nesse espaço heterotópico. Heróis não são os que invadiram, conquistaram e dominaram. Heróis são os que resistiram e lutaram. Que não se renderam diante da barbárie. Na bandeira dessa "multidão verde e rosa", no lugar de "ordem e progresso", as palavras "índios, negros e pobres" rodeadas de bandeiras com os rostos de Marielle Franco, Cartola, Jamelão, Carolina de Jesus, Mussum, entre outros rostos. Rostos dos nossos heróis e heroínas, segundo a intenção do carnavalesco. Se o samba e o desfile são espaços heterotópicos, isso supõe que eles têm um sistema de abertura e de fechamento que, ao mesmo tempo, os distancia e os torna penetráveis (FOUCAULT, 2013). Assim, o samba e o desfile abrem a história para novos personagens e fecham para outros, que são reinventados como assassinos, criminosos, sonegadores.

Isso evidencia que a história contada nesses carros alegóricos propõe outro currículo. Essas definições e entendimentos que a Mangueira apresentou e defendeu reforçam o lugar do desfile como contraespaço, mas é necessário que aqueles que o estão assistindo assim o compreendam, o que não se pode assegurar, visto que o currículo é o espaço do incontrolável. "Incontrolável porque em um currículo sempre há espaço para os encontros que escapam ao controle, que resistem e extrapolam ao planejado, que se abrem para a novidade" (PARAÍSO, 2016, p. 390). Portanto, mesmo que a escola de samba tenha buscado construir o que chamamos de uma contra-história e entre no campo de disputa do currículo, isso não é garantia de sucesso. Para esse currículo presente no samba conseguir seu investimento, é preciso que se desdobre em outros espaços, como as salas de aula e as escolas.

Isso posto, pode-se dizer que, com arte e muito samba no pé, entre as formas e forças do carnaval, a Mangueira criou um contraespaço e uma contra-história. Outrossim, entre a forma da narrativa tradicional e a força de uma narrativa que ficou "fora" dos livros, reescreveu 
uma nova história e um novo currículo. Uma história contada não apenas nas palavras do samba-enredo campeão, mas também nos corpos daqueles que insistem em resistir e lutar por um país em que o povo seja, de fato, reconhecido e respeitado: negros, índios e pobres, mulheres, todos e todas tornaram-se uma multidão verde e rosa e fizeram da alegria uma potência para a vida, acreditando que, com essa heterotopia, dos “"engravidados' de novas ideias, jorrará leite novo para 'amamentar' os guris que virão. Sabendo de outra versão de quem é o Brasil - não a que nos 'ninou' para quando fôssemos adultos" (VIEIRA, 2018, n.p.). Assim, será "possível que reconheçam em si a bravura que vive à espreita da hora de despertar e aí, talvez, o 'gigante desperte sem ser para se distrair com a TV"” (VIEIRA, 2018, n.p.).

O desfile da Mangueira fez borrar a história oficial e o currículo tradicional em busca de uma nova história e um novo currículo que trouxessem para dentro dele vidas que importam. Um momento e tempo que nos mostram que "há 'sujeitos' que não são exatamente reconhecíveis como sujeitos e há 'vidas' que dificilmente - ou, melhor dizendo, nunca - são reconhecidas como vidas" (BUTLER, 2018, p. 17). Um desfile que não somente foi o grande vencedor do ano de 2019, mas também causou grande impacto nos meios de comunicação, nas escolas, nos cursos de formação, visto que se aproximou da história (algo que não é novo entre as escolas de samba) e problematizou um fazer história com clara reivindicação de um novo discurso sobre a história do Brasil, um novo currículo, por assim dizer. Um currículo que ensina, mobiliza, faz sambar e aprender uma contra-história, que se tornou realidade ao inventar um contraespaço. Afirmamos, assim, que este aconteceu no encontro de diferentes espaços, entre formas e forças. Nesse sentido, queremos pensar essas ações do contraespaço e da contrahistória nas práticas docentes, quando se busca colocar sob suspeita nossos currículos.

\section{CONSIDERAÇÕES FINAIS}

O samba-enredo precisa ser contado a partir do desfile. É imprescindível o contato entre formas e forças para as invenções que problematizamos aqui. Assim, entre a força da letra da música e as formas dos corpos que interpretavam as vidas que merecem estar na história, invencionou-se uma heterotopia. São os corpos generificados que contam essa contra-história e que efetivam esse espaço como contraespaço. Corpos que, ao se unirem, dizem: "nós não somos descartáveis". O que eles dizem em suas existências é que ainda estamos aqui, 
persistindo, reivindicando mais justiça, uma fuga da precariedade, a possibilidade de uma vida que possa ser vivida, como nos ensina Butler (2018). Louro (2011, p. 65) nos lembra que, "no contexto da sociedade brasileira, ao longo de sua história, foi sendo produzida uma norma a partir do homem branco, heterossexual, de classe média urbana e cristão". Ao construir a história a partir desses parâmetros de gênero e sexualidade, foram definidas vidas precárias, vidas que não são passíveis de luto e que, no decorrer da história, sofreram e ainda sofrem com o feminicídio, a LGBTTIfobia, o massacre dos povos indígenas e a necropolítica. Quando utilizamos o samba e o desfile para pensar as heterotopias no currículo, vemo-nos implicados na política das subjetividades e nos outros espaços para além da Sapucaí, aqueles em que o desfile pode se desdobrar em novas construções e continuidades. As subjetividades são produções discursivas, ancoradas nos contextos históricos de sua formação, o que nos impede de falar de negritude ou de homossexualidade em um sentido único, assim como da categoria homem ou mulher. As subjetividades são o resultado de processos históricos, e mexer na História é desestabilizar as construções e as relações das subjetividades, como o samba e o desfile parecem apostar.

Butler (2018, p. 17), ao trabalhar com o corpo como forma de resistência às condições de vida que tornam determinados corpos precários e mais vulneráveis do que outros, provocanos...

Neste momento em que a economia neoliberal estrutura cada vez mais as instituições e os serviços públicos, o que inclui escolas e universidades, em um momento em que as pessoas, em números crescentes, estão perdendo casa, benefícios previdenciários e perspectivas de emprego, nós nos deparamos, de uma maneira nova, com a ideia de que algumas populações são consideradas descartáveis.

Olhar para as vidas precárias em seu direito de existir e aparecer em público é uma aspiração política das análises de Butler (2018) no investimento por tornar a vida das minorias sexuais e de gênero como mais possíveis e mais suportáveis. Corpos que, no desfile, tomaram outros lugares, transformando-se em heróis e heroínas, representando personagens negros e negras da história não contada em muitos currículos. Mulheres e povos que são convocados/as e reconhecidos/as como sujeitos da história para dizer que a história do Brasil não é feita exclusivamente por homens brancos vitoriosos, católicos e heterossexuais. Para Butler (2018), assim como para Scott (1995), o gênero é uma construção relacional complexa, em aberto (em 
disputa) e sujeita a negociações entre os gêneros e no interior do próprio gênero, não se limitando ao patriarcado, o que potencializa o desfile e suas propostas de afetar o currículo. $\mathrm{O}$ gênero vai se constituindo como um organizador social, ligado aos saberes localizados, um entendimento importante para desnaturalizar e deslegitimar as diferentes formas de violência e opressão que afetam pessoas que não se enquadram na norma heterossexual branca e que estão ancoradas nas maneiras como escrevemos e contamos nossa história.

Se a escola e o currículo são convocados para o desfile, para o diálogo e negociação com os saberes que o desfile apresenta, o inverso também acontece, ou seja, outros espaços podem e devem se transformar em contraespaços na escola e nos currículos. Assim, problematizamos como o desfile e outros artefatos nos fazem inventar contraespaços curriculares, por exemplo, as escolas. A sala de aula não é o lugar do senso comum, ela tem responsabilidade com o rompimento desse senso comum a partir de outras formas de saber e conhecer. Problematizar é colocar o que pensamos e fazemos em meio à história do pensamento. O currículo e o ensino de História nos conduzem para a necessidade de pensarmos o que sabemos e o que somos como resultado de produção discursiva, da história do pensamento e, por consequência, na problematização da história do pensamento como prática de liberdade dos modos dispersos pelos quais nos tornamos o que somos hoje. O ensino de História é, potencialmente, um campo do conhecimento que nos mostra que nossa realidade, nossas maneiras de pensar e agir não são algo dado, mas resultado de processos históricos. Nesse sentido, o currículo de História pode ser considerado em constante construção, e não como acabado. Esse é o grande desafio da formação docente, ou seja, tomar o conhecimento (e, especificamente, o conhecimento histórico) como resultado de produção discursiva, que constitui sujeitos.

Pensar que os espaços são constituídos e constituem currículos nos levou a problematizar como o samba-enredo pode nos inspirar para criarmos contraespaços, alargando as possibilidades dos currículos. Em tempos de enfrentamentos contra a diferença, entendemos que é possível inventar heterotopias onde não parece haver espaço. Enxergar nas brechas, nas fronteiras entre as formas e forças um lugar para a invenção. Para tanto, é necessário não deixarmos morrer em nós o desejo, ao nos depararmos com os espaços tristes nos territórios do currículo. O desejo por inventar espaços alegres que contemplem a diferença que é a vida, a singularidade, a heterogeneidade. Não nos esqueçamos, como nos lembra o samba-enredo aqui 
analisado, de que "na luta é que a gente se encontra". Encontra-se para produzir espaços alegres, contraespaços, heterotopias tais que, quiçá, inspirarão vidas que não serão mais passíveis de luto, antes, serão vida possíveis de viver. Contraespaços que nos farão viver o que até então é considerado invivível no currículo.

\section{REFERÊNCIAS}

BUTLER, Judith. Quadros de guerra: quando a vida é passível de luto? Tradução Sérgio Tadeu de Niemeyer Lamarão e Arnaldo Marques da Cunha. Rio de Janeiro: Civilização Brasileira, 2018.

DIAS, Susana Oliveira; MARQUES, Davina; AMORIM, Antônio Carlos. Forças, fluxos e devires. In: IAS, Susana Oliveira; MARQUES, Davina; AMORIM, Antônio Carlos (Orgs.). Conexões: Deleuze e arte e ciência e acontecimento e... Petrópolis: De Petrus, 2012. p. 9-16.

FOUCAULT, Michel. As palavras e as coisas. São Paulo: Martins Fontes, 1999.

FOUCAULT, Michel. Em defesa da sociedade. Tradução M. E. Galvão. São Paulo: Martins Fontes, 2005.

FOUCAULT, Michel. A vida dos homens infames. In: FOUCAULT, Michel. Em defesa da sociedade. Tradução M. E. Galvão. São Paulo: Martins Fontes, 2005. p. 75-98.

FOUCAULT, Michel. Ditos e escritos III. Estética: literatura e pintura, música e cinema. Rio de Janeiro: Forense Universitária, 2009.

FOUCAULT, Michel. O corpo utópico, as heterotopias. São Paulo: N-1 Edições. 2013.

JENKINS, Keith. A história repensada. Tradução Mário Vilela. São Paulo: Contexto, 2011.

LOPES, Alice Casimiro. Apostando na produção contextual do currículo. In: AGUIAR, Márcia Ângela; DOURADO, Luiz Fernandes (Orgs.). A BNCC na contramão do PNE 2014-2024: avaliação e perspectivas. Recife: ANPAE, 2018. p. 23-27. [Livro eletrônico].

LOURO, Guacira Lopes. Educação e docência: diversidade, gênero e sexualidade. Revista Brasileira de Pesquisa sobre Formação Docente, v. 3, n. 4, p. 62-70, jan./jul. 2011.

Disponível em: https://revformacaodocente.com.br/index.php/rbpfp/article/view/31. Acesso em: 12 jun. 2021.

NEGRI, Antônio. Exílio. São Paulo: Iluminuras, 2001.

NIETZSCHE, Friedrich. Vontade de potência. Tradução, prólogo [O homem que foi um campo de batalha] e notas por Mário Ferreira dos Santos. Petrópolis: Vozes, 2011. 
PARAÍSO, Marlucy Alves. Diferença no currículo. Cadernos de Pesquisa, v. 40, n. 140, p. 587-604, maio/ago. 2010. Disponível em:

https://www.scielo.br/pdf/cp/v40n140/a1440140.pdf. Acesso em: 12 jun. 2021.

PARAÍSO, Marlucy Alves. Um currículo entre formas e forças. Educação, Porto Alegre, v. 38, n. 1, p. 49-58, jan./abr. 2015. Disponível em:

https://revistaseletronicas.pucrs.br/ojs/index.php/faced/article/view/18443. Acesso em: 12. jun. 2021.

PARAÍSO, Marlucy Alves. A ciranda do currículo com gênero, poder e resistência.

Currículo sem Fronteiras, v. 16, n. 3, p. 388-415, set./dez. 2016. Disponível em:

http://www.curriculosemfronteiras.org/vol16iss3articles/paraiso.pdf. Acesso em: 12. jun.

2021.

PARAÍSO, Marlucy Alves. Currículo, gênero e heterotopias em tempos de slogan "ideologia de gênero". In: LOPES, Alice Casimiro; OLIVEIRA, Anna Luiza A. R. Martins de; OLIVEIRA, Gustavo Gilson Sousa de. Os gêneros da escola e o (im)possível silenciamento da diferença no currículo. Recife: Ed. UFPE, 2018. p. 211-242.

PELBART, Peter. Texto de abertura da série cordéis político "Pandemia", constituída pela N1 edições, editora parceira em Outros Quinhentos. 2017. Disponível em: https://outraspalavras.net/desigualdades-mundo/peter-pal-pelbart-estamos-em-guerra/. Acesso em: 8 jul. 2019.

POCAHY, Fernando Altair. A pesquisa fora do armário: ensaio de uma heterotopia queer. 2006. Dissertação (Mestrado em Psicologia Social e Institucional) - Universidade Federal do Rio Grande do Sul, Porto Alegre, 2006.

RANNIERY, Thiago. Manifesto Beyoncé no currículo: a força da música e o brilho erótico do corpo que dança. In: PARAÍSO, Marlucy; CALDEIRA, Maria Carolina da Silva (Orgs.). Pesquisas sobre currículos, gêneros e sexualidades. Belo Horizonte: Mazza Edições, 2018. p. 199-218.

SCOTT, Joan Wallach. Gênero: uma categoria útil de análise histórica. Educação \& Realidade, Porto Alegre, v. 20, n. 2, p. 71-99, jul./dez. 1995. Disponível em: https://www.seer.ufrgs.br/educacaoerealidade/article/viewFile/71721/40667. Acesso em: 12 jun. 2021.

VIEIRA, Leandro. Mangueira 2019: Sinopse. Galeria do Samba. Rio de Janeiro. 2018. Disponível em: http://www.galeriadosamba.com.br/espaco-aberto/topico/mangueira-2019sinopse/229852/?fbclid=IwAR37NvPINW522FhGkIywMyFwphODwZx07rYn7EBCt4YHd NkSLXA53s9_WjU. Acesso em: 15 out. 2019. 


\section{NOTAS:}

${ }^{1}$ Utilizamos a palavra "História", com letra maiúscula, quando se tratar da disciplina de História nos currículos escolares. Quando se referir a "história" de modo geral, faremos uso da palavra em letra minúscula.

${ }^{2}$ Para mais detalhes, ver: https://www.redebrasilatual.com.br/cultura/2019/10/samba-mangueira-2020-favela/. Acesso em: 2 nov. 2019.

3 Disponível em: http://www.galeriadosamba.com.br/espaco-aberto/topico/mangueira-2019sinopse/229852/?fbclid=IwAR37NvPINW522FhGkIywMyFwphODwZx07rYn7EBCt4YHdNkSLXA53s9_WjU . Acesso em: 19 out. 2019.

${ }^{4}$ Essa citação de Pelbart (2017) foi extraída do texto de abertura da série de cordéis político "Pandemia", constituída pela N-1 edições, editora parceira em Outros Quinhentos, e, por isso, está sem identificação do número de página. Disponível em: https://outraspalavras.net/desigualdades-mundo/peter-pal-pelbart-estamos-em-guerra. Acesso em: 8 jul. 2019.

${ }^{5}$ Disponível em: https://www.youtube.com/watch?v=scKZBmi3-F0. Acesso em: 17 out. 2019.

${ }^{6}$ Fala de Leandro Vieira, carnavalesco da Mangueira. Disponível em: http://www.galeriadosamba.com.br/espacoaberto/topico/mangueira-2019-

sinopse/229852/?fbclid=IwAR37NvPINW522FhGkIywMyFwphODwZx07rYn7EBCt4YHdNkSLXA53s9_WjU . Acesso em: 2 nov. 2019.

${ }^{7}$ Esse quadro ficou popularmente conhecido como $O$ grito do Ipiranga.

Recebido em: 07/11/2019

Aprovado em: 05/08/2020 